International Journal of Biology, Pharmacy and Allied Seiences (IJBPAS)

'A Bridge Betueen Caboratory and QRando'

WwW.ibpas.com

\title{
PLASMA NEOPTERIN AS AN INFLAMMATORY MARKER IN PREGNANT WOMEN WITH PREECLAMPSIA IN SOUTH INDIAN POPULATION; A CROSS SECTIONAL STUDY
}

\section{SANKAR $\mathrm{A}^{\mathbf{1}}$, SHENBAGA LALITHA $\mathrm{S}^{\mathbf{2}^{*}}$ AND K.SUMATHI ${ }^{3}$}

1: Associate Professor, Department of General Medicine, Sree Balaji Medical College \&

$$
\text { Hospital, Chrompet Chennai-600044 }
$$

2: Assistant Professor, Department of Biochemistry, Sree Balaji Medical College \& Hospital, Chrompet, Chennai-600044

3: Associate Professor, Department of Biochemistry, Sree Balaji Medical College \& Hospital, Chrompet, Chennai-600044

*Corresponding Author: Dr. S. Shenbaga Lalitha: E Mail: dr.lalittha@gmail.com Received 28 ${ }^{\text {th }}$ Dec. 2020; Revised $27^{\text {th }}$ Jan. 2021; Accepted $16^{\text {th }}$ Feb. 2021; Available online $1^{\text {st }}$ Oct. 2021 https://doi.org/10.31032/IJBPAS/2021/10.10.5638

\section{ABSTRACT}

Preeclampsia is a life threatening complication of pregnancy. Almost 5-6 percent of women are presented with preeclampsia in developing countries. To evaluate plasma neopterin as inflammatory marker in pregnant women with Preeclampsia. This is a cross sectional study done in south Chennai during the period of 2017-2019. After getting consent, 100 pregnant women with Gestational age 20-34 weeks was selected. Pregnant women with Diabetes, Hypertension, Renal disease, previous history of preeclampsia, multiple gestations were excluded from the study. Preeclampsia was diagnosed by gestational hypertension $(\geq 140 / 90 \mathrm{mmHg}$ ) with proteinuria $(24 \mathrm{hr}$ urine protein $\geq 300 \mathrm{mg})$ after 20 weeks of pregnancy. Of which, 25 pregnant women are diagnosed with mild preeclampsia ( $24 \mathrm{hr}$ urine protein $\geq 300 \mathrm{mg}$ ), 25 pregnant women are diagnosed with severe preeclampsia (24hr urine protein $\geq 5 \mathrm{~g}$ ) was considered as cases and 50 pregnant women without any pregnancy complications was considered as controls. Plasma samples were drawn from the participants for the estimation of Neopterin using EDTA vacutainers. Plasma neopterin levels less than $10 \mathrm{nmol} / \mathrm{L}$ is considered normal and more than $10 \mathrm{nmol} / \mathrm{L}$ is considered as elevated. Statistical analysis 
was done using SPSS software. There is no statistically significant mean difference between maternal age, maternal weight, gestational age during sampling time. Mean difference between Plasma neopterin levels in women with mild preeclampsia was $15.1 \mathrm{nmol} / \mathrm{L}$, pregnant women with severe preeclampsia was $16.2 \mathrm{nmol} / \mathrm{L}$ and in control group, the mean plasma concentration of plasma neopterin levels was $8 \mathrm{nmol} / \mathrm{L}$. ( $\mathrm{p}$ value -0.001 ). The spearmen's rank correlation test of plasma neopterin levels are highly correlated in women with the severity of preeclampsia $(\mathrm{r}=0.534, \mathrm{p}=0.00)$, which is statistically significant. Our study data showed that Plasma neopterin concentrations are higher in pregnant women with preeclampsia than pregnant women without complications. Also increasing neopterin levels are well correlated with severity of preeclampsia. So, plasma Neopterin can be used as a clinical biomarker in predicting the severity of preeclampsia in future.

\section{Keywords: Neopterin, Preeclampsia, Pregnancy}

\section{INTRODUCTION}

Preeclampsia is a pregnancy related complication which leads to mortality and morbidity in mother as well as in newborn. Almost three to six percent of pregnant women have preeclampsia in pregnancy. Studies shown that the incidence of preeclampsia is 7 times more in developing countries when compared to developed countries [1]. The pathogenesis of Preeclampsia is not clearly understood till now. Studies reported that Inflammation, Endothelial and placental dysfunction are the main contributors to the pathophysiology of preeclampsia. Early detection and proper follow up is more important in preeclampsia to avoid maternal and neonatal morbidity \& mortality. An inflammatory marker, Neopterin is synthesised and released from activated human macrophages and monocytes. Neopterin is a reliable and specific marker of innate inflammation. And it is biologically stable and easily measured in human body fluids [2]. According to previous studies; inflammatory cytokines such as Neopterin are reported to be seen in higher concentrations in women with preeclampsia than women without pregnancy induced complications [3]. so we aimed at investigating the plasma concentrations of Neopterin in pregnant women with preeclampsia \& pregnant women without complications.

\section{MATERIALS \& METHODS}

The study was conducted after obtaining ethical clearance from the institutional ethical board committee. in a private medical college situated in south Chennai during the year 2017-2019.After obtaining informed consent from the study participants, 100 pregnant women with the 
gestational age of $20-34$ weeks in the age group between 20-30 years were recruited for the study. Pregnant women with Diabetes, Hypertension, Renal disease, previous history of preeclampsia, multiple gestations were excluded from the study. Demographic details were recorded. Weight was measured using a standardized weighing balance. Preeclampsia was diagnosed by gestational hypertension $(\geq 140 / 90 \mathrm{mmHg})$ with proteinuria $(24 \mathrm{hr}$ urine protein $\geq 300 \mathrm{mg}$ ) after 20 weeks of pregnancy. Of which, 25pregnant women are diagnosed with mild preeclampsia $(24 \mathrm{hr}$ urine protein $\geq 300 \mathrm{mg}$ ), 25 pregnant women are diagnosed with severe preeclampsia ( $24 \mathrm{hr}$ urine protein $\geq 5 \mathrm{~g}$ ) was considered as cases and 50 pregnant women without any pregnancy complications was considered as controls. Plasma samples were drawn from the participants for the estimation of Neopterin using EDTA vacutainers plasma neopterin was measured using Enzyme linked immunosorbent assay kit method. Plasma neopterin levels less than $10 \mathrm{nmol} / \mathrm{L}$ is considered normal and more than $10 \mathrm{nmol} / \mathrm{L}$ is considered as elevated. Statistical analysis was done using SPSS software.

\section{RESULT}

Table 1 showed the mean difference between various parameters among pregnant women with preeclampsia and pregnant women without any complications. There is no statistically significant difference between maternal age, maternal weight, gestational age during sampling time. Table 2 showed the mean difference between Plasma neopterin levels in women with mild preeclampsia was $15.1 \mathrm{nmol} / \mathrm{L}$, pregnant women with severe preeclampsia was $16.2 \mathrm{nmol} / \mathrm{L}$ and in control group, the mean plasma concentration of plasma neopterin levels was $8 \mathrm{nmol} / \mathrm{L}$. (p value -0.001). Graph 1 shows the spearmen's rank correlation test of plasma neopterin levels are highly correlated in women with the severity of preeclampsia $(\mathrm{r}=0.534, \mathrm{p}=0.00)$, which is statistically significant.

Table 1: Mean difference between various parameters among pregnant women with preeclampsia and pregnant women without complications

\begin{tabular}{|c|c|c|c|}
\hline Parameters & Preeclampsia (mild \& Severe) & $\begin{array}{c}\text { Pregnant women without } \\
\text { complications }\end{array}$ & P value \\
\hline Maternal years (age) & $\mathbf{2 5 . 1 2}$ & $\mathbf{2 4 . 9 6}$ & $\mathbf{0 . 2}$ \\
\hline Maternal weight & $\mathbf{6 8 . 4}$ & $\mathbf{6 1 . 4 2}$ & $<\mathbf{0 . 0 0 0 0 1}$ \\
\hline $\begin{array}{c}\text { Gestational age at } \\
\text { sampling }\end{array}$ & $\mathbf{3 0 . 0 6}$ & $\mathbf{2 9 . 4 6}$ & $\mathbf{0 . 1}$ \\
\hline
\end{tabular}

( $P$ value significant at the level of 0.05 )

Table 2: Mean difference between Plasma Neopterin levels among pregnant women with preeclampsia (mild \& severe) and pregnant women without complications

\begin{tabular}{|c|c|c|c|c|}
\hline Parameter & Mild preeclampsia & Severe preeclampsia & $\begin{array}{c}\text { Pregnant women without } \\
\text { complications }\end{array}$ & P value \\
\hline NEOPTERIN & $15.1 \mathrm{nmol} / \mathrm{L}$ & $16.2 \mathrm{nmol} / \mathrm{L}$ & $\mathbf{8 n m o l} / \mathbf{L}$ & 0.001 \\
\hline
\end{tabular}

( $P$ value significant at the level of 0.05 ) 


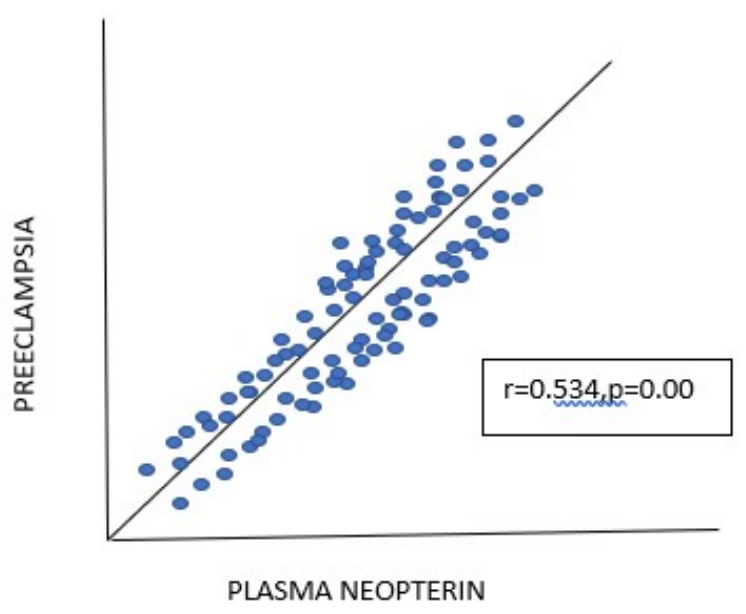

Graph 1: Spearmen rank correlation test between plasma Neopterin levels \&pregnant women with Preeclampsia ( $P$ value significant at the level of 0.05 )

\section{DISCUSSION}

In our study, plasma Neopterin was highly correlated with the pregnant women with preeclampsia. Our study also showed that the plasma neopterin levels increases with the severity of preeclampsia. Similar evidences were reported by study done Ozler et al $[\mathbf{4}, \mathbf{5}]$. Neopterin is synthesised from GTP (guanosine triphosphate) in monocytes \& macrophages with the help of the enzyme guanosine triphosphate cyclohydrolase. This enzyme activity is increased by cytokines. Hence it is serves as a reliable inflammatory marker in preeclampsia. Hence, it can be used to predict the severity of preeclampsia, thereby preventing life threatening complications such as HEELP syndrome \& eclampsia. Neopterin levels are also increased in other inflammatory condition such as crohn's disease \& ulcerative colitis, infections such as malaria, sepsis and some autoimmune diseases such as rheumatoid arthritis \& thyroiditis. A study reported that increase in plasma neopterin concentrations are also associated with preterm delivery [6]. Fetal growth restriction [7]. Since our study is a small study, but still it is promising, plasma Neopterin can be used as a clinical biomarker for predicting the severity \& follow up of preeclampsia only after future large scale studies.

\section{CONCLUSION}

Our study data showed that Plasma neopterin concentrations are higher in pregnant women with preeclampsia than pregnant women without complications. Also increasing neopterin levels are well correlated with severity of preeclampsia. So, plasma Neopterin can be used as a clinical biomarker in predicting the severity of preeclampsia in future. 


\section{REFERENCES}

[1] Malik A, Jee B, Gupta SK. Preeclampsia: Disease biology and burden, its management strategies with reference to India. Pregnancy hypertension. 2019; 15: 23-31.

[2] Fuchs D, Weiss G, Wachter H. Neopterin, biochemistry and clinical use as a marker for cellular immune reactions. Int Arch Allergy Immunol. 1993; 101(1): 1-6.

[3] vonVersen-Hoeynck FM, Hubel CA, Gallaher MJ, Gammill HS, Powers RW. Plasma levels of inflammatory markers neopterin, sialic acid, and C-reactive protein in pregnancy and preeclampsia. Am J Hypertens. 2009; 22(6): 687-92.

[4] Ozler A, Turgut AB, Sak ME, Evsen MS, Soydinc HE, Evliyaoglu O, Gul T. Serum levels of neopterin, tumor necrosis factoralpha and Interleukin-6 in preeclampsia: relationship with disease severity. Eur Rev Med Pharmacol Sci. 2012; 16(12): 17072.

[5] Pergialiotis V, Karampetsou N, Zoumpourlis $\mathrm{P}$, Papantoniou $\mathrm{N}$, Thomakos N, Daskalakis G. Serum neopterin levels in women with preeclampsia: a systematic review. Hypertension in pregnancy. 2018; 37(4): 220-6.
[6] Keskin U, Ulubay M, Kurt YG, Fidan U, Koçyiğit YK, Honca T, Aydin FN, Ergün A. Increased neopterin level and chitotriosidase activity in pregnant women with threatened preterm labor. The Journal of Maternal-Fetal \& Neonatal Medicine. 2015; 28(9): 1077-81.

[7] Erkenekli K, Keskin U, Uysal B, Kurt YG, Sadir S, Çayci T, Ergün A, Erkaya S, Danişman N, Uygur D. Levels of neopterin and Creactive protein in pregnant women with fetal growth restriction. J of Obstetrics and Gynaecology. 2015; 35(3): 225-8. 